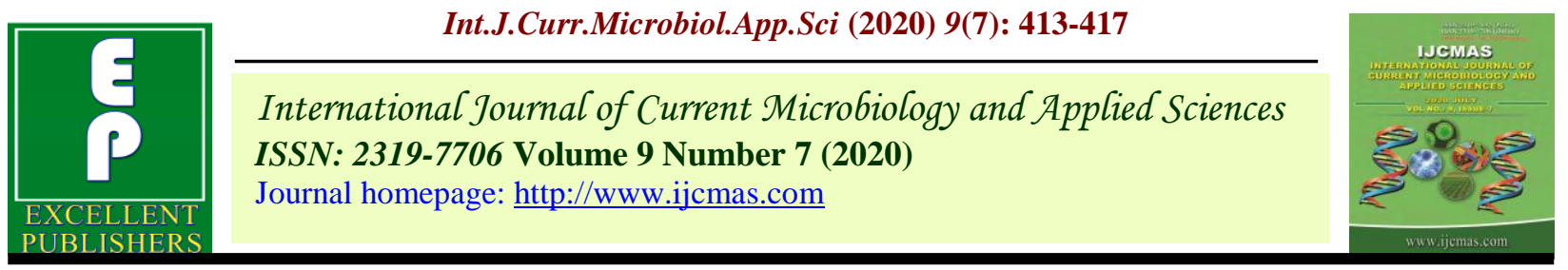

Original Research Article

https://doi.org/10.20546/ijcmas.2020.907.046

\title{
Effect of Supplementation of Fiber Degrading Enzymes on Digestibility of Nutrients in Broiler Chickens Fed Diets Containing De-Oiled Rice Bran
}

\author{
P. Anuradha ${ }^{1}$ and Barun Roy ${ }^{2}$ \\ ${ }^{1}$ Institute of Animal Nutrition, Tamil Nadu Veterinary and Animal Sciences University, \\ Kattupakkam, Tamil Nadu - 603 203, India \\ ${ }^{2}$ Department of Animal Nutrition, West Bengal University of Animal and Fishery Sciences, \\ Kolkatta, West Bengal-700037, India \\ *Corresponding author
}

\section{A B S T R A C T}

\begin{tabular}{|l|}
\hline Ke y w or d s \\
Broiler, DORB, \\
Nutrient \\
digestibility, \\
Xylanase \\
\hline Article Info \\
\hline $\begin{array}{l}\text { Accepted: } \\
\text { 05 June 2020 } \\
\text { Available Online: } \\
\text { 10 July 2020 }\end{array}$ \\
\hline \hline
\end{tabular}

\begin{abstract}
A study was conducted to evaluate the effect of supplementation of xylanase enzyme on nutrient utilization of broiler chicken fed de-oiled rice bran based ration. One hundred and sixty unsexed day-old broiler chicks belonging to a single hatch, were purchased, weighed and randomly allotted in to five experimental groups, comprising two replicates of sixteen chicks each. The experimental diets were $\mathrm{T}_{\mathrm{c}^{-}}$Control (3\% CF without xylanase), $\mathrm{T}_{1}-3 \%$ CF with xylanase, $\mathrm{T}_{2}-3.5 \%$ CF with xylanase, $\mathrm{T}_{3}-4 \% \mathrm{CF}$ with xylanase and $\mathrm{T}_{4}-4.5 \%$ $\mathrm{CF}$ with xylanase. Xylanase supplemented at the rate of $10 \mathrm{~g} / 100 \mathrm{~kg}$ feed. Dry matter and ether extract digestibility was similar in all treatment groups. The apparent digestibility of crude fiber was significantly $(\mathrm{P}<0.05)$ higher in treatment group than that of control. The apparent digestibility of crude protein was significantly $(\mathrm{P}<0.05)$ higher only in $\mathrm{T} 1(3 \% \mathrm{CF}$ with xylanase) group compared to control. Apparent metabolizable energy (AME) value of the treatment diet was significantly $(\mathrm{P}<0.05)$ lower, when compared to unsupplemented low fiber diet. It was concluded that supplementation of xylanase enzyme to de-oiled rice bran based diet increases digestibility of crude fiber and crude protein, hence can be included in broiler diet to improve performance.
\end{abstract}

\section{Introduction}

The most important constraint in the development of poultry industry in India is the shortage of conventional feed ingredients. The exorbitant cost of conventional feed ingredients necessitates a search for alternate feed ingredients and developing strategies to increase the utilization of known existing feed ingredients. In India many more unconventional feed ingredients are produced in plenty, among that de-oiled rice bran is one of the cheapest ingredient, abundantly produced agricultural by product.

Usage of this feed ingredient, as feed for poultry is however limited due to their high fiber content called as Non-starch polysaccharides (NSP). These NSPs have anti-nutritive effects, increases intestinal 
viscosity which slows down the absorption of nutrients (Vooren, 2012). Poultry do not produce endogenous enzymes to digest the beta type linkages of Non-starch polysaccharides (NSP) (Saki et al., 2011). Supplementation of NSP degrading enzymes in broiler diet improves litter quality, nutrient utilization and therefore production efficiency (Khusheeba Munir and Sajid Maqsood, 2013). Supplementation of exogenous enzymes to the ration, increases digestibility, removes anti-nutritional factors and improves nutrient availability (Fernando et al., 2008). Hence, the present study was conducted to investigate the effect of xylanase enzyme supplementation on digestibility of nutrients in broiler chickens fed de-oiled rice bran based ration.

\section{Materials and Methods}

One hundred and sixty unsexed day-old broiler chicks (vencobb) were purchased, weighed and randomly distributed in to five experimental groups, comprising two replicates of sixteen chicks each. They are, $\mathrm{T}_{\mathrm{c}}$ control (3\% CF without xylanase), $\mathrm{T}_{1}(3 \% \mathrm{CF}$ with xylanase), $\mathrm{T}_{2}(3.5 \% \mathrm{CF}$ with xylanase), $\mathrm{T}_{3}$ (4\% CF with xylanase) and $\mathrm{T}_{4}(4.5 \% \mathrm{CF}$ with xylanase). Xylanase supplemented at the rate of $10 \mathrm{~g} / 100 \mathrm{~kg}$ feed. The experimental diets were formulated to meet or exceed BIS (1992) recommendations for all the nutrients (Table 1). Crude fiber content in broiler feed was raised to the respective level by incorporating De-oiled rice bran (DORB). All the rations were formulated to be isocalorific and isonitrogenous. The enzyme tested was a commercial enzyme premix (Lumifeed xylanase) having the enzyme activity of $70,000 \mathrm{IU} / \mathrm{gm}$. At the end of the sixth week of the in vivo trial, a digestion trial for a period of 3 days was conducted for estimation of digestibility of nutrients and Apparent metabolizable energy (AME). The daily total feed intake, residual feed and total faecal output were recorded. During the digestibility study birds were allowed ad libitum access to feed and water. During the collection period, excreta were collected twice daily from each cage for three consecutive days and weighed to record the total quantity of droppings voided per day. The excreta were dried in hot air oven at $60^{\circ} \mathrm{C}$ to a constant weight for estimation of DM content.

Experimental diets, DORB and faecal samples were estimated for the proximate principles namely moisture, crude protein, ether extract, crude fiber and total ash as per the methods of AOAC (1990). NFE was calculated by difference. Apparent faecal digestibility of DM, OM, CP, EE, CF were calculated as follows:

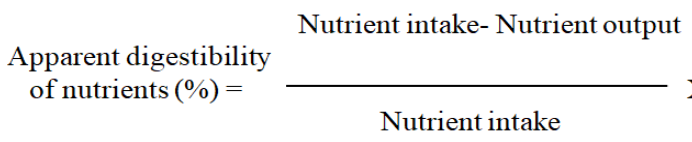

Gross energy content of the feed and faecal samples were determined by using bomb calorimeter and the Apparent metabolizable energy (AME) was calculated. Data was analyzed by using SPSS ${ }^{\mathrm{TM}}$ VERSION (10.0). The Duncan range test was used to determine difference among treatment means for significant dietary effect (Snedecor and Cochran, 2004) with $\mathrm{p}<0.05$ considered statistically significant unless otherwise noted.

\section{Results and Discussion}

The apparent digestibility (\%) of DM, CP, EE, CF, TA and NFE of different treatment diets are presented in Table 2. The apparent digestibility of $\mathrm{CF}$ was significantly $(\mathrm{P}<0.05)$ higher in treatment group than control group. Among the treatment groups $\mathrm{T}_{1}$ recorded highest CF digestibility value followed by $\mathrm{T}_{2}$, $\mathrm{T}_{4}, \mathrm{~T}_{3}$ and control. The result gives an impression that xylanase supplementation had 
effects on CF content of experimental diets. Similarly, Shyamsunder et al., (2007) also reported increased fiber digestibility with xylanase supplementation on feeding $15 \%$ de-oiled rice bran based diet in broilers. Solubilization of cell walls by enzyme supplementation may be responsible for the improvement in digestibility of nutrients. Apparent digestibility of CP was significantly $(\mathrm{P}<0.05)$ higher only in $\mathrm{T}_{1}$ when compared to control $\left(\mathrm{T}_{\mathrm{c}}\right)$. Apparent digestibility of TA and NFE were significantly $(\mathrm{P}<0.05)$ lower in high fiber treatment group when compared to low fiber group.

No significant $(\mathrm{P}<0.05)$ variation was noticed in DM and EE digestibility, among all the groups. This is in agreement with findings of Bilal et al., (2016), who found that supplementation of NSP-ase enzyme in sunflower meal based diet did not show improvement in DM, CP, EE, CF digestibility in broilers. Whereas, significant improvement in apparent digestibility of DM, CP, EE and $\mathrm{CF}$ with exogenous enzyme supplementation was reported by Iyayi and Davies, (2005) and Khan et al., (2006). The results on Apparent metabolizable energy (AME) value of experimental diets are presented in Table 3.

Apparent metabolizable energy of diet was significantly $(\mathrm{P}<0.05)$ higher in control than treatment groups. Similar findings observed by Davood sharifi et al., (2012) who reported that supplementation of enzymes at three level 0,300 and $600 \mathrm{~g} /$ ton of feed with hull less barley diet did not improve AME in broiler diet. Nian et al., (2011) also found that supplementation of xylanase enzyme at $4000 \mathrm{U} / \mathrm{kg}$ feed to broilers fed corn-soy based diet did not significantly affect diet AME values.

Table.1 Per cent Ingredient Composition of Experimental Diets

\begin{tabular}{|l|l|l|l|l|l|l|l|l|l|l|}
\hline \multirow{2}{*}{ Ingredients } & \multicolumn{7}{|c|}{ Experimental diets } \\
\cline { 2 - 11 } & \multicolumn{7}{|c|}{ Starter ration } \\
\cline { 2 - 12 } & $\mathbf{T}_{\mathbf{c}}$ & $\mathbf{T}_{\mathbf{1}}$ & $\mathbf{T}_{\mathbf{2}}$ & $\mathbf{T}_{\mathbf{3}}$ & $\mathbf{T}_{\mathbf{4}}$ & $\mathbf{T}_{\mathbf{c}}$ & $\mathbf{T}_{\mathbf{1}}$ & $\mathbf{T}_{\mathbf{2}}$ & $\mathbf{T}_{\mathbf{3}}$ & $\mathbf{T}_{\mathbf{4}}$ \\
\hline Maize & 59.5 & 59.5 & 56.5 & 52.0 & 47.8 & 59.3 & 59.3 & 56.6 & 53.0 & $\mathbf{4 9 . 5}$ \\
\hline DORB & 1.2 & 1.2 & 4.5 & 9.0 & 13.5 & 1.0 & 1.0 & 4.9 & 8.8 & $\mathbf{1 3 . 0}$ \\
\hline Soyabean meal & 35.0 & 35.0 & 34.5 & 34.0 & 33.0 & 34.0 & 34.0 & 32.6 & 32.0 & $\mathbf{3 0 . 8}$ \\
\hline Oil & 1.0 & 1.0 & 1.2 & 1.8 & 2.4 & 2.5 & 2.5 & 2.7 & 3.0 & $\mathbf{3 . 5}$ \\
\hline Calcite & 1.0 & 1.0 & 1.0 & 1.0 & 1.0 & 0.9 & 0.9 & 0.9 & 0.9 & $\mathbf{0 . 9}$ \\
\hline DCP & 1.2 & 1.2 & 1.2 & 1.2 & 1.2 & 1.2 & 1.2 & 1.2 & 1.2 & $\mathbf{1 . 2}$ \\
\hline Methionine & 0.19 & 0.19 & 0.19 & 0.17 & 0.2 & 0.17 & 0.17 & 0.17 & 0.17 & $\mathbf{0 . 1 7}$ \\
\hline Lysine & 0.17 & 0.17 & 0.17 & 0.17 & 0.17 & 0.17 & 0.17 & 0.17 & 0.17 & $\mathbf{0 . 1 7}$ \\
\hline Soda & 0.2 & 0.2 & 0.2 & 0.2 & 0.2 & 0.2 & 0.2 & 0.2 & 0.2 & $\mathbf{0 . 2}$ \\
\hline Bicarbonate & & & & & & & & & \\
\hline Salt & 0.2 & 0.2 & 0.2 & 0.2 & 0.2 & 0.2 & 0.2 & 0.2 & 0.2 & $\mathbf{0 . 2}$ \\
\hline TM Mix $*$ & 0.15 & 0.15 & 0.15 & 0.15 & 0.15 & 0.15 & 0.15 & 0.15 & 0.15 & $\mathbf{0 . 1 5}$ \\
\hline Premix $* *$ & $\mathbf{0 . 2}$ & $\mathbf{0 . 2}$ & $\mathbf{0 . 2}$ & $\mathbf{0 . 2}$ & $\mathbf{0 . 2}$ & $\mathbf{0 . 2}$ & $\mathbf{0 . 2}$ & $\mathbf{0 . 2}$ & $\mathbf{0 . 2}$ & $\mathbf{0 . 2}$ \\
\hline
\end{tabular}

TM Mix* contained $\mathrm{Fe} \mathrm{SO}_{4}, \mathrm{Cu} \mathrm{SO}_{4}, \mathrm{Zn} \mathrm{SO}_{4}, \mathrm{Mn} \mathrm{SO}_{4}$, Potassium Iodide, Sodium Selenite and DCP as base Premix** contained necessary Vitamins, Choline chloride, Anticoccidial agents, Emulsifiers and Acidifiers 
Table.2 Apparent digestibility (\%) of DM, CP, EE, CF, TA and NFE of the experimental diets $($ Mean $\pm \mathrm{SE})$

\begin{tabular}{|c|c|c|c|c|c|}
\hline \multirow[t]{2}{*}{ Parameters } & \multicolumn{5}{|c|}{ Treatments } \\
\hline & $\mathbf{T}_{\mathbf{C}}$ & $\mathbf{T}_{1}$ & $\mathbf{T}_{2}$ & $\mathbf{T}_{\mathbf{3}}$ & $\mathbf{T}_{4}$ \\
\hline DM & $77.1 \pm$ & $77.46 \pm$ & $76.50 \pm$ & $76.84 \pm$ & $76.55 \pm$ \\
\hline $\mathbf{C P}$ & $\begin{array}{c}71.67^{b} \pm \\
0.254\end{array}$ & $\begin{array}{c}73.08^{c} \pm \\
0.047\end{array}$ & $\begin{array}{c}71.52^{\mathrm{ab}} \\
0.528\end{array}$ & $\begin{array}{c}70.90^{\mathrm{a}} \pm \\
0.446\end{array}$ & $\begin{array}{c}71.48^{\mathrm{ab}} \\
0.211\end{array}$ \\
\hline EE & $\begin{array}{c}78.98 \pm \\
0.001\end{array}$ & $\begin{array}{c}78.32 \pm \\
0.004\end{array}$ & $\begin{array}{c}78.64 \pm \\
0.008\end{array}$ & $\begin{array}{c}78.00 \pm \\
0.002\end{array}$ & $\begin{array}{c}78.03 \pm \\
0.041\end{array}$ \\
\hline $\mathbf{C F}$ & $\begin{array}{c}31.09^{\mathrm{a}} \pm \\
0.258\end{array}$ & $\begin{array}{c}37.6^{\mathrm{e}} \pm \\
0.514\end{array}$ & $\begin{array}{c}35.21^{\mathrm{d}} \pm \\
0.177\end{array}$ & $\begin{array}{c}32.79^{b} \pm \\
0.254\end{array}$ & $\begin{array}{c}33.04^{c} \pm \\
0.258\end{array}$ \\
\hline TA & $\begin{array}{c}42.8^{c} \pm \\
0.263\end{array}$ & $\begin{array}{c}42.3^{c} \pm \\
0.254\end{array}$ & $\begin{array}{c}41.40^{b} \pm \\
0.259\end{array}$ & $\begin{array}{c}41.81^{b} \pm \\
0.002\end{array}$ & $\begin{array}{c}40.90^{\mathrm{a}} \pm \\
0.047\end{array}$ \\
\hline NFE & $\begin{array}{c}64.35^{c} \pm \\
0.247\end{array}$ & $\begin{array}{c}64.15^{c} \pm \\
0.217\end{array}$ & $\begin{array}{c}63.61^{b} \pm \\
0.554\end{array}$ & $\begin{array}{c}62.61^{a} \pm \\
0.369\end{array}$ & $\begin{array}{c}62.40^{\mathrm{a}} \pm \\
0.214\end{array}$ \\
\hline
\end{tabular}

${ }^{\mathrm{a}-\mathrm{d}}$ Values within columns with no common superscripts are significantly different $(\mathrm{P}<0.05)$ according to Duncan's multiple range test; Values presented as mean \pm standard error

Table.3 Effects of dietary treatment on Apparent metabolizable energy (AME) values

\begin{tabular}{|c|c|c|c|c|c|}
\hline \multirow[b]{2}{*}{ Parameters } & \multicolumn{5}{|c|}{ Treatments } \\
\hline & Tc & T1 & T2 & T3 & $\mathbf{T 4}$ \\
\hline $\begin{array}{l}\text { GE of feed } \\
(\mathrm{kcal} / \mathrm{kg})\end{array}$ & $\begin{array}{c}4098.13^{\mathrm{a}} \\
\pm 0.514\end{array}$ & $\begin{array}{c}4062.97^{b} \\
\pm 0.147\end{array}$ & $\begin{array}{c}4000.49^{c} \\
\pm 0.267\end{array}$ & $\begin{array}{c}3960.76^{\mathrm{d}} \\
\pm 1.024\end{array}$ & $\begin{array}{c}3950.93^{\mathrm{e}} \\
\pm 1.047\end{array}$ \\
\hline $\begin{array}{l}\text { GE of Faeces } \\
(\mathrm{kcal} / \mathrm{kg})\end{array}$ & $\begin{array}{l}3329.53^{\mathrm{a}} \\
\pm 0.145\end{array}$ & $\begin{array}{l}3310.17^{b} \\
\pm 0.258\end{array}$ & $\begin{array}{c}3296.33^{c} \\
\pm 0.347\end{array}$ & $\begin{array}{c}3156.46^{\mathrm{e}} \\
\pm 0.333\end{array}$ & $\begin{array}{c}3196.16^{d} \\
\pm 0.254\end{array}$ \\
\hline AME & $\begin{array}{c}3358.19^{a} \\
\pm 0.547\end{array}$ & $\begin{array}{c}3317.55^{b} \\
\pm 0.249\end{array}$ & $\begin{array}{c}3227.55^{d} \\
\pm 0.897\end{array}$ & $\begin{array}{l}3241.11^{c} \pm \\
0.114\end{array}$ & $\begin{array}{c}3200.27^{\mathrm{e}} \\
\pm 0.215\end{array}$ \\
\hline
\end{tabular}

In conclusion, xylanase enzyme supplementation to de-oiled rice bran based high fiber diet increases digestibility of crude fiber and crude protein of the diet and can be used in poultry diet to improve performance and economic viability.

\section{References}

AOAC, 1990. Official methods of analysis $\left(15^{\text {th }}\right.$ Edn). Association of Official Analytical Chemists, Arlington, VA.

Bilal, M., Mirza, M.A., Kaleem, M., Saeed, M., Reyad- ul-ferdous, Md. and Abd El-Hack, M.E. 2016. Significant effect of NSP-ase enzyme supplementation in sunflower meal-based diet on the growth and nutrient digestibility in broilers. J. Anim. Physiol. Anim. Nutr., 101(2), 222-228.

BIS, 1992. Bureau of Indian standards for poultry feeds. Bureau of Indian Standards (BIS), Bahadur Shah Zafarmarg, New Delhi.

Davood sharifi, S., Shariatmadari, F. and Yaghobfar, A. 2012. Effects of inclusion of hull-less barley and enzyme supplementation of broiler diets on growth performance, nutrient digestion and dietary metabolizable 
energy content. J. Cent. Eur. Agric., 13(1), 193-207.

Fernando, G., Costa, P., Goulart, C. C., Figueiredo, D.F., Oliveira, C.F.S. and Silva, J. H. A. 2008. Economic and environmental impact of using exogenous enzymes on poultry feeding. Int.J. Poult. Sci., 7: 311-314.

Iyayi, E. A., and Davies, B. I. 2005. Effect of Enzyme Supplementation of Palm Kernel Meal and Brewer's Dried Grain on the Performance of Broilers. Int. J. Poult. Sci., 4(2): 76-80.

Khan, S. H., Sardar, R. and Siddique, B. 2006. Influence of enzymes on performance of broilers fed sunflowercorn based diets. Pak. Vet. J., 26(3): 109-114.

Khusheeba Munir and Sajid Maqsood, 2013. A review on role of exogenous enzyme supplementation in poultry production. Emir. J. Food Agric. 25 (1): $66-80$.

Nian, F., Guo, Y. M., Ru, Y. J., Peron, A. and Li, F.D. 2011. Effect of Xylanase Supplementation on the Net Energy for Production, Performance and Gut Microflora of Broilers Fed Corn/Soybased Diet. Asian-Aust. J. Anim. Sci., 24 (9): 1282 - 1287.

Saki, A. A., Hemati Matin, H. R., Zamani, P. and Mirzaaghatabar, F. 2011. NonStarch Polysaccharides and Broiler Responses. World Appl. Sci. J., 15 (2): 192-198.

Shyam sunder., G, Arun kumar, A, Rani gupta, Vijay kumar, C., Panda, A. K., Rama rao, S. V. S., Raju, M. V. L. N. and Reddy, M. R. 2007. Effect of xylanase on body weight gain, digestibility of NSP and nutrients, and bone mineralization in broiler chickens fed de-oiled rice bran diets. Proceedings of $24^{\text {th }}$ IPSACON, 25-27 April, Ludhiana, India. pp. 72

Snedecor, G.W. and Cochran,W.G. 2004. Statistical Methods. $8^{\text {th }}$ Edn., Oxford and IBH Publications, New Delhi, India.

Vooren, N.V. 2012. Flexible feed formulation with multi enzyme concept. Pak. Poult., 33: 7-11.

\section{How to cite this article:}

Anuradha. P and Barun Roy. 2020. Effect of Supplementation of Fiber Degrading Enzymes on Digestibility of Nutrients in Broiler Chickens Fed Diets Containing De-Oiled Rice Bran. Int.J.Curr.Microbiol.App.Sci. 9(07): 413-417. doi: https://doi.org/10.20546/ijcmas.2020.907.046 